MA NATALIJA DIMIĆ, Research Assistant

Institute for Recent History of Serbia

Belgrade, Republic of Serbia

natalijadimic@gmail.com

UDK 94:327(497.1:430.1)"1949/1951"

94:339(497.1:430.1)"1949/1951"

94:355.257.7(=112.1)(497.1)"1949/1953"

originalan naučni rad / original scientific paper

primljeno / received: 9. 11. 2020.

prihvaćeno / accepted: 19. 5. 2021.

https://doi.org/10.29362/ist20veka.2021.2.dim.333-352

\title{
CONNECTING TRADE AND POLITICS: NEGOTIATIONS ON THE RELEASE OF THE GERMAN PRISONERS OF WAR IN YUGOSLAVIA AND THE FIRST WEST GERMAN- YUGOSLAV TRADE AGREEMENT OF 1949/1950
}

ABSTRACT: This paper analyzes the multipronged approach the West German authorities embraced in their relations with Yugoslavia during the early 1950s. By focusing on the issue of repatriation of the remaining 1,400 German prisoners of war in Yugoslavia, the author attempts to show how West Germany, lacking political power, resorted to its economic strength in order to achieve its political goals. The article, based on unpublished German and Yugoslav sources, follows the discussions about trade and economic cooperation as well as discussions on the future release of German POWs and analyzes how and when those issues intertwined.

KEYWORDS: German Prisoners of War, Federal Republic of Germany, Yugoslavia, German-Yugoslav relations, Trade Agreement, Repatriation, War Crimes

The end of World War II brought about a new European order. However, the long shadow of the war lingered on for years. ${ }^{1}$ The term Zero Hour (German: Stunde Null) meant liberation for very few Germans. The majority saw 8 May as a moment of defeat, the beginning of foreign occupation, and continued suffering. More than 130 German cities were razed by allied bombings, communication and infrastructure networks lay in ruins, famine and disease ran rampant, as did crime and the black market. Millions of Germans were left homeless and the situation was only exacerbated by refugees flowing in from the East. More than 12 million Germans were expelled from Poland, Czechoslovakia, Yugoslavia, Romania, and other Eastern European countries. Between 8 and 10 million Germans were internally displaced and in need of shelter. With this in mind, most Germans considered themselves as victims. ${ }^{2}$

\footnotetext{
${ }^{1}$ Tony Judt, Postwar. A History of Europe since 1945 (New York: The Penguin Press, 2005), 6.

2 Christoph Kleßmann, Die doppelte Staatsgründung. Deutsche Geschichte 1945-1955 (Bonn: BpB, 1991), 37-53.
} 
After the German Instrument of Surrender was signed, around 11 million former German soldiers were imprisoned in over 20 countries - ca. 3 million in the USSR, 3.8 million in the US, 3.7 million in the UK, and 245,000 in France. ${ }^{3}$ According to official Yugoslav data published in Borba on 8 February 1949, 221,287 prisoners of war had been detained in Yugoslavia in 1945, among them 84,453 German and 27,398 Austrian citizens. ${ }^{4}$ The total number of Wehrmacht soldiers who ended up in Yugoslav hands in May of 1945 was probably higher than the official Yugoslav data reveals. However, the number of those that died during the first weeks and months from illness, hunger, poor living conditions, or fell victim to torture and revenge, has not been determined so far. ${ }^{5}$ The majority of captive Germans stemmed from Army Group E, which had been retreating from Greece and Albania under the command of Colonel General Alexander Löhr. Among them were members of the 41 st Fortress Division, mostly made up of conscripts from the 999 Penal Battalion; political prisoners of Nazi Germany, socialists, and communists, freed from the concentration camps in order to fight in the war. ${ }^{6}$

Over the summer of 1945, the Yugoslav authorities became aware of the potential economic benefits they could gain from their German prisoners of war. ${ }^{7}$ At the same time, first spontaneous steps toward political education

${ }^{3}$ In the Fall of 1945, almost 900,000 German POWs were detained in France, as ca. 700,000 Germans were sent from the United States and the UK to France in order to assist French economic recovery. Jürgen Weber, Kleine Geschichte Deutschlands seit 1945 (München: Deutscher Taschenbuch Verlag, 2002), 10; Arthur L. Smith, Jr., „Die deutschen Kriegsgefangenen und Frankreich 1945-1949“, Vierteljahrshefte für Zeitgeschichte, 32, no. 1, (1984), 105.

4 „Saopštenje Ministarstva unutrašnjih poslova FNRJ o repatrijaciji ratnih zarobljenika, Beograd, 8. februara 1949“, Dokumenti o spoljnoj politici Socijalističke Federativne Republike Jugoslavije 1949 (Beograd: Jugoslovenski pregled, 1991), 12.

${ }^{5}$ In German historiography, figures reach 200-240,000 German and Austrian POWs in Yugoslavia. See: Kurt W. Böhme, Die deutschen Kriegsgefangenen in Jugoslawien 1941-1949, Band I/1 (Bielefeld: Verlag Ernst und Werner Giesking, 1976), 42. East and West German analyses from 1948-1950 indicate that ca. 80-84,000 Germans were imprisoned in Yugoslavia. It is therefore highly probable that after the first months of uncontrolled murders, famine, and poor living conditions, the number of German POWs in Yugoslav camps amounted to ca. 84,000. See: Politisches Archiv des Auswärtigen Amtes (PA AA), Büro der Staatssekretäre (B2), 63, Die Lage der deutschen Minderheit in Jugoslawien; Stiftung Archiv der Parteien und Massenorganisationen-Bundesarchiv Berlin/Lichterfelde (SAPMO-Barch), Sozialistische Einheitspartei Deutschlands (DY 30)/71033, LPKK Berlin, Max Wilhelm Hermann Sens, Aktennotiz betr. Hans Becker, 4. 2. 1950. Milan Terzić also discussed the issue of the exact number of German POWs in Yugoslavia. See: Милан Терзић, „Јосип Броз Тито и Немци - ратни заробљеници“, Војноисторијски гласник, бр. 2, (2015), 164-175.

${ }^{6}$ See: K. W. Böhme, Die deutschen Kriegsgefangenen in Jugoslawien 1941-1949, I/1, 37-41; Erich Schmidt-Richberg, Der Endkampf auf dem Balkan. Die Operationen der Heeresgruppe E von Griechenland bis zu den Alpen (Heidelberg: Scharnhorst Buchkammeradschaft, 1955); Karl Hnilicka, Das Ende auf dem Balkan 1944-1945. Die Militärische Räumung Jugoslawiens durch die deutsche Wehrmacht (Zürich-Frankfurt: Musterschmidt, 1970); Dušan Lukač, Treći Rajh i zemlje Jugoistočne Evrope, knj. 3 (Beograd: Vojnoizdavački novinski centar/Balkanološki institut SANU, 1987), 405-787; Završne operacije za oslobođenje Jugoslavije (Beograd: Vojnoistorijski institut, 1957).

7 For a thorough analysis of German workers in Yugoslavia, see: Саша Илић, „Странци гастарбајтери": Страна стручна радна снага у привреди Југославије 1945-1955 
of POWs were taking place in camps throughout the country. The educators were most commonly prewar anti-fascists and former political prisoners. Soon, steps were made to organize the previously uncoordinated efforts, and anti-fascist committees (known as ANTIFA) that had sprung up all over Yugoslav camps. The central anti-fascist committee in Belgrade, headed by prewar German communist Karl Wloch, coordinated their activities. When he left for the Soviet Occupation Zone in Germany in 1946, Adolf Ische, also a prewar communist, took over. Anti-fascist committees were entrusted with complete political and cultural training of German prisoners. In the fall of 1945, first prisoners' newspapers were launched and since 1946 political courses had been organized, as well as cultural, sports, and workers' manifestations. On the one hand, the aim of the committees was to motivate the prisoners to work on rebuilding Yugoslavia. Also, by confronting them with the consequences of the war and occupation, a Yugoslav denazification method of sorts was implemented. Prisoners were confronted with the collective responsibility of the German nation for the outbreak of the war and its consequences and through the motto "whilst rebuilding Yugoslavia we work for Germany" they were promised redemption. On the other hand, political reeducation of prisoners also strived to model and create reliable cadres capable of participating in the "democratic renewal of Germany" upon returning home. Until 1948, these activities were closely coordinated with the Communist Party of Germany (since April 1946 the Socialist Unity Party of Germany). The first train transports which departed from Yugoslavia in 1946 carried therefore not only weak and sick prisoners, but also many German anti-fascists, who soon became members of the Communist Party of Germany. ${ }^{8}$ Prewar anti-fascists and newly reeducated prisoners alike became the faces of Yugoslav-German friendship and a positive image of Yugoslavia in Germany, thus becoming an important pillar in Yugoslavia's foreign political propaganda. ${ }^{9}$

(Београд: Архив Југославије, 2020); Saša Ilić, „Vrednovanje rada i životni uslovi nemačkih ratnih zarobljenika zaposlenih u privredi Jugoslavije 1945-1949“, Istorija 20. veka, XXXVII, br. 2, (2019), 157-176.

${ }^{8}$ Numerous sources state that many prisoners joined the Antifa committees for opportunistic reasons, not for their ideological convictions. For example, a former German prisoner's report partly published in Sopade Bulletin stated that in early 1946 out of all German POWs in Yugoslavia only 3\% were registered as anti-fascists. This share increased to $7 \%$ in May, and to $20 \%$ in November the same year. The reasons for the rise were explained with the fact that in the meantime the rumors had spread that the anti-fascists were the first to be repatriated to Germany. See: Bundesaechiv-Koblenz (BAK), Z 35 (Deutsches Büro für Friedensfragen)/487, "Die Lage der deutschen Kriegsgefangenen in Jugoslawien. Stand vom 20. November 1946", Sopade Informationsdienst, 3. 2. 1947. German POWs were facing similar situation in French camps as well. First to be repatriated were the elderly, the ill, and those who could prove their anti-fascist activities during the war. Arthur L. Smith, Jr., op. cit., 103-121.

${ }^{9}$ More on anti-fascist committees and reeducation of German POWs in Yugoslavia, see: K. W. Böhme, Die deutschen Kriegsgefangenen in Jugoslawien 1941-1949, I/1, 285-370; С. Илић, „Странции гастарбајтери“, 246-250; S. Ilić, „Vrednovanje rada...“, 171-174; Наталија Димић, „На обнови Југославије радимо за Немачку: немачки заробљеници, антифашисти, пропагандисти“, Токови историје, бр. 2, (2020), 75-105. 
However, some prisoners, mostly chosen from the anti-fascist committees, cooperated with the Yugoslav state security. They were in charge of detecting war criminals among the prisoners and their former brothers in arms. While some were swayed in their personal political and ideological convictions, many had simpler opportunistic reasons (more generous food rations, cigarettes, clothing, money, promises of a speedy return home, and threats of a prolonged incarceration). Many former prisoners who were not repatriated during the first transports despite being sick, or who were kept in Yugoslavia under charges of war crimes despite being innocent, later placed the blame for their mishandling not only on the Yugoslav authorities, but also on the anti-fascist committee members. More often than not, Karl Wloch and Adolf Ische were personally named. Those who had in their opinion suffered unjustly because of Wloch's and Ische's denunciations, considered them responsible for this "sad episode of the German national embarrassment", ${ }^{10}$

Cordial relations between Yugoslav and the East German party leaders ended abruptly following the Cominform Resolution of June 1948. However, as the agreement that the repatriation of prisoners would be concluded by the end of 1948 had previously been reached in Moscow in 1947, the Yugoslav-Soviet split did not influence the treatment of the majority of remaining German POWs in Yugoslavia. Between November 1948 and January 18, 1949 over 50,000 Germans were repatriated from Yugoslavia. According to Yugoslav authorities, not a single German POW remained in Yugoslavia and repatriations were formally over. However, some former prisoners remained in Yugoslavia voluntarily and signed employment contracts with Yugoslav companies. In addition, around 1,400 former soldiers, mostly from the Waffen SS, as well as various security and intelligence detachments, marine and aviation officers remained in Yugoslav prisons. ${ }^{11}$ According to Yugoslav data, this number was exactly 1,348 prisoners - 976 of whom were under investigation, and 372 of whom had already been charged with war crimes. ${ }^{12}$

The issue of the remaining prisoners of war was on the minds of many Germans. However, divided into occupational zones, lacking central institutions and diplomatic representatives, and subjected to the decisions of the occupiers, postwar Germany proved incapable of solving the issue of its remaining prisoners of war. ${ }^{13}$ Yugoslavia was not the only country that kept German soldiers and

${ }^{10}$ BAK, Z 35/488, Abschrift. Informationen eines Heimhekrers aus jugoslawischer Kriegsgefangenschaft über die Kriueggefangenschaft in Jugoslawien, 15. 2. 1949.

${ }^{11}$ BAK, Z 35/488, Abschrift: Die deutschen Kriegsgefangenen in Jugoslavien (Ein zusammenfassender Berlicht auf Grund von Heimkehreraussagen), 21. 3. 1949; Bundesministerium für Wirtschaft (B 102)/6194, Die Lage der deutschen Kriegsgefangenen in Jugoslawien.

12 „Saopštenje Ministarstva unutrašnjih poslova FNRJ o repatrijaciji ratnih zarobljenika, Beograd, 8. februara 1949“, Dokumenti..., 12.

${ }^{13}$ In 1947, the Allies allowed founding institutions responsible for the issues of German POWs. Consequently, the Zentralverband der Heimkehrer and the Bundesverband der Heimkehrer were founded. They merged into Verband der Heimkehrer in 1950, as a department within the Ministry for refugees. Besides, the Deutsches Büro für Friedensfragen existed between 1947 
officers under arrest on charges of war crimes. In fact, in France, more than a thousand Germans remained under arrest on charges of war crimes after December of 1948. ${ }^{14}$ The Soviet Union also had more than 30 thousand German prisoners, who were repatriated in the aftermath of Konrad Adenauer's visit to Moscow in the summer of 1955. Yugoslavia's position was somewhat unique, as it was not a great power, and therefore the fact that it still held German prisoners was a much bigger embarrassment to the newly formed West German Government. ${ }^{15}$ The Yugoslav-Soviet split paved the way for establishing economic, political, and cultural relations between Yugoslavia and the Federal Republic of Germany, which in turn provided the West German Government with a means of exerting pressure on Belgrade regarding the remaining prisoners in a way it could not pressure France or the USSR. By publicly pressuring Yugoslavia, Chancellor Adenauer signaled to his constituents that he cared deeply for German national interests and that he was not, as his opposition claimed, an allied rather than a federal chancellor. Having in mind the difficult economic situation of the post-1948 Yugoslavia, the main fields in which the Federal Republic of Germany could apply pressure were economic and/or financial.

Mostly all reports written by former German prisoners following their return from Yugoslavia stated that the first weeks and months of captivity had been remarkably hard. ${ }^{16}$ However, after the situation stabilized in the POW camps, food rations as well as clothing and entertainment improved. ${ }^{17}$ In fact, the experiences of former prisoners varied greatly. For some, captivity lasted only a year, some were treated better due to their anti-fascist leanings, some were given better paid and less tedious tasks due to their expertise, some remained voluntarily in Yugoslavia, and even married and settled in the country permanently. On the other hand, many suffered greatly during the time of their captivity. ${ }^{18}$ However,

and 1949, and was responsible for collecting documents related to future peace settlement with Germany, and to German POWs as well. However, the only way these institutions could contribute to improving the living conditions of German POWs, or to their release, was either through the International Red Cross, or by appealing to the Allied occupation authorities, who were only rarely sympathetic to their pleas. See: James Diehl, The Thanks of the Fatherland: German Veterans after the Second World War (Chapel Hill-London: The University of North Carolina Press, 1993), e-book, 71-72; L. Smith, Jr., op. cit., 103-121.

${ }^{14}$ L. Smith, Jr., op. cit., 103-121.

${ }^{15}$ Federal Republic of Germany was founded on May 23, 1949. Following the August elections, the first Federal government headed by Chancellor Konrad Adenauer was formed on September 15, when the Occupation Statute of Germany was put into force. The Occupation Statute regulated relations between the FRG and the western allies, especially the issues of foreign policy and foreign trade, the Ruhr, reparations, restitution, war criminals, and demilitarization. With certain changes, the Occupation Statute remained in force until May 5, 1955. „Besatzungsstatut", in: Deutsche Geschichte im 20. Jahrhundert. Ein Lexikon, Hrsg. Axel Schildt (München: C. H. Beck, 2005), 64-65; Dominik Geppert, Die Ära Adenauer, 2. Auflage (Darmstadt: WBG, 2007), 7-10.

16 See prisoners' reports in: BAK, Z 35/488.

${ }^{17}$ BAK, Z 35/488, Abschrift: Die deutschen Kriegsgefangenen in Jugoslavien (Ein zusammenfassender Berlicht auf Grund von Heimkehreraussagen), 21. 3. 1949.

${ }^{18}$ In November 1948, West German press reported that the repatriates from Yugoslavia were well dressed, healthy, and generally in far better condition than those returning from the USSR or 
those who remained in Yugoslavia after January 18, 1949 faced months filled with uncertainty and hardship.

The news agency $d p d^{19}$ reported on 21 January 1949 that the last official transport from Yugoslavia had reached Ulm, which formally marked the end of the repatriation process, but that the fates of the officers held in Camp No. 233 near the town of Vršac had remained unknown. From that camp, only 30 officers had been repatriated to western occupation zones through the Soviet Occupation Zone of Germany. ${ }^{20}$ When Yugoslav authorities proclaimed that the repatriation was officially over, the remaining German soldiers were stripped of their POW status and the Geneva Convention protection. During the first months of 1949, the remaining German prisoners were given less food, no letters, and their movements were strictly limited. In his report regarding the fates of German prisoners in Yugoslavia, the last chief of the general staff of Army Group E, Erich Schmidt-Richberg, himself a former prisoner of war, claimed that despite the fact that the terms of imprisonment were generally good, the officers and soldiers of the Wehrmacht who had remained in Yugoslavia underwent four months of torture. According to him, under the guise of legal procedures the Yugoslav authorities committed "mass crimes". ${ }^{21}$ Neither the prisoners' families nor the relevant German authorities had precise knowledge about the remaining prisoners in Yugoslavia. In their analyses, the West German authorities relied on previously repatriated prisoners' assumptions and statements. $^{22}$ Some news arrived through unofficial channels, as the prisoners sent word to their families through intermediaries that they were barred from sending and receiving letters, but that they were allowed to receive food packages from home. They mostly asked for food, as the rations in Yugoslav prisons were decreasing over time. Such partial information about mishandling of the prisoners received great attention of the German public. ${ }^{23}$

During the same period, the prospects for establishing meaningful economic cooperation between the two countries were increasing by the day. Vari-

Poland. BAK, Z 35/487, “Die Heimkehrertransporte aus dem Osten”, Ulm, im November 1948 (DPD, 30.11.48); "Heimkehr aus Jugoslavien. Die ersten Kriegsgefangenentransporte im Durchgangslager Ulm eingetroffen", Rhein-Neckar-Zeitung, 27. 11. 1948.

${ }^{19}$ Deutsche Pressedienst (dpd) was a news agency founded in the British Occupation Zone of Germany. In August 1949, dpd merged with news agencies from the US (Deutsche Nachrichtenagentur, DENA) and French zones of occupation (Süddeutsche Nachrtichtenagentur, Südena) into Deutsche Presse-Agentur (dpa), which has remained the biggest news agency in Germany.

${ }^{20}$ BAK, Z 35/487, Dpd, Letzted Heimkehrertransport aus Jugoslawien eingetroffen, Ulm, 21.1. 1949.

${ }^{21}$ BAK, Bundespräsidialamt (B 122)/552, Über das Schicksal der deutschen Kriethat gsgefangenen in Jugoslawien und das deutsch-jugoslawische Verhältnis. 1951. Even Yugoslav authorities criticized mishandling of German prisoners who remained in Yugoslavia under accusation of war crimes. At the Central Committee Session in June of 1951, Aleksandar Ranković criticized the way court trials were conducted. See: С. Илић, Странци „гастарбајтери “, 255.

22 BAK, Z 35/487, Abschrift, Walter Schmiedel an den Sacharbeiter für Kriegsgefagenenwesen z.Hd. von Herrn Schneider, 25. 3. 1949.

${ }^{23}$ BAK, Z 35/487, Abschrift, betr. Deutsche Kriegsgefangene in Jugoslavien, 27. 5. 1949. 
ous West German institutions pointed out that the Federal Republic and Yugoslavia were "natural" trade partners with complementary economies. ${ }^{24}$ Yugoslav trade representatives were already aware during the spring of 1949 that German companies were eager to trade with Yugoslavia, assuming that a breakthrough into the German market was possible. ${ }^{25}$ However, the unsolved issue of prisoners and the aftermath of the war more generally, still remained an obstacle.

As early as mid-1949 the ministry of economy in Bonn was bombarded with pleas to integrate the fates of the remaining prisoners into the impending trade negotiations with Yugoslavia. ${ }^{26}$ In December of 1949, when the Yugoslav trade delegation arrived in West Germany to discuss the new trade agreement, these concerns had already been shared by the German leaders as well. ${ }^{27}$ Adhering to the instructions from the chancellor, Economy Minister Ludwig Erhard mentioned the issue of the remaining German prisoners in Yugoslavia during a banquet prior to the first round of official negotiations. He said the issue was very important to the general public in Germany and that its favorable resolution would undoubtedly improve prospects for successful economic cooperation. ${ }^{28}$ Similar statements were made by CarlHermann Mueller ${ }^{29}$ on 22 December 1949, following the successful conclu-

${ }^{24}$ For complementary nature of Yugoslav and German economies, and their entanglements prior to WWII, see: Vuk Vinaver, Svetska ekonomska kriza u Podunavlju i nemački prodor 19291935 (Beograd: Institut za savremenu istoriju, 1987); Andrej Mitrović, "Ergänzungswirtschaft: the Theory of an Integrated Economic Area of the Third Reich and Southeast Europe 19331941", in: The Third Reich and Yugoslavia 1933-1945 (Beograd: Institut za savremenu istoriju /Narodna knjiga, 1977), 7-45; Wolfgang Schumann, "Aspekte und Hintergründe der Handelsund Wirtschaftspolitik Hitler-Deutschlands gegenüber Jugoslawien", in: The Third Reich and Yugoslavia, 221-239; Душан Лукач, „Привредна експанзија Немачке према Југоистоку Европе 1933-1937“, Balcanica, br. 11, (1980), 163-177; Андреј Митровић, "Deutschland und Jugoslawien 1919-1933”, Зборник Филозофског факултета, књ. XII, бр. 1, (1974), 567-575; Perica Hadži-Jovančić, The Third Reich and Yugoslavia: An Economy of Fear, 19331941 (Bloomsbury, 2020); Милена С. Коцић, „Економски односи Краљевине Југославије и Немачке од 1929. до 1941. године“ (докторска дисертација, Универзитет у Нишу, Филозофски факултет, Департман за историју, 2019).

25 Arhiv Jugoslavije (AJ), fond 9, Ministarstvo spoljne trgovine Vlade FNRJ, 63, Vjekoslav Milun, Trgovinska delegacija FNRJ u Frankfurtu na Majni - Ministarstvu spoljne trgovine FNRJ, Odseku za Nemačku, 11. 2.1949.

${ }^{26}$ BAK, B 102/6194, Frau Gertrud Sand an Herrn Prof. Ludwig Erhard, 10. 8. 1949; Dr. jur. v. Waldow an Herrn Ministerialdirektor Frhr. von Maltzan, 18. 11. 1949.

${ }^{27}$ After the Occupation Statute was put into force, the FRG institutions were entrusted with negotiating foreign trade agreements and customs, but were obliged to inform the Allied High Commission about their beginning and outcome. Furthermore, the High Commission retained the right to approve, or reject any agreement. See: "Budnesminister Erhard an Bundeskanzler Adenauer, 25. Oktober 1949”, Hrsg. Hans-Peter Schwarz, Akten zur Auswärtigen Politik der Bundesrepublik Deutschland 1949/1950 (München: R. Oldenbourg Verlag, 1997), 8-9.

${ }^{28}$ BAK, B 102/6194, Telefonische Durchsage an Herrn von Trütschler, 5. 12. 1949; Vermerk. Anruf der Verwaltung für Wirtschaft, 6. 12. 1949; Vermerk, 6. 12. 1949; L. Erhard an den Herrn Bundeskanzler, 7. 12. 1949.

${ }^{29}$ Before the WWII, Carl-Hermann Mueller was employed first the Ministry of Economy, and then in the Ministry of Foreign Affairs. He was also a NSDAP member. Since the summer of 1949, he was the head of the Department for East and Southeast Europe in the Economic Ad- 
sion of the negotiations. ${ }^{30}$ Mueller said that Minister Erhard was expecting a reply on the Yugoslav position regarding the remaining prisoners. ${ }^{31}$ Despite the assurances given by the Yugoslav representatives on both occasions, no concrete steps were undertaken to resolve the issue. On the contrary, news arrived from Yugoslavia that collective verdicts had been reached in December of 1949, which further alarmed the German public. ${ }^{32}$

Although the trade agreement had not been officially ratified yet, the $\mathrm{Yu}-$ goslav Foreign Trade Ministry was certain in January of 1950 that its provisions were already in effect, which was soon corroborated by the German side. ${ }^{33}$ The agreement was extremely important for the Yugoslavs, as the goals of their 5-year plan were jeopardized significantly by the economic blockade from the East. Therefore, during December of 1949 and January of 1950, 10,000 out of the agreed 40,000 tons of scrap metal had already been exported to Yugoslavia. However, in January of 1950, newspaper articles began appearing in the West German press tying the ratification of the agreement with the release of the remaining German prisoners. The German side assured the Yugoslavs that the sole reason the West German Government had not yet approved the agreement was because the Allied High Commission's approval was still missing. Nevertheless, the German side implied that the articles in the press reflected the general opinion of the German people, which the Federal government had to take into consideration. ${ }^{34}$

The issue of prisoners detained in Yugoslavia was discussed at the $32^{\text {nd }}$ Bundestag session on 27 January 1950. Chancellor Adenauer underlined that the situation regarding the remaining German citizens in Yugoslavia was "disturbing." He drew attention to the fact that the Yugoslav authorities had responded to the Federal government's appeals both through the Allied High Commission (which was skeptical about the outcome), and through "other means" (most likely referring to this issue being raised during the December 1949 trade negotiations) by issuing collective verdicts. He therefore concluded that these developments did not support the ratification of the trade agreement with Yugoslavia. His conclusions were met with cries: Sehr richtig! ${ }^{35}$ Adenauer's speech was a clear public protest

ministration and since 1950 employed in the West German Ministry of Economy. He was the first West German Ambassador to Austria. See: Pape, Matthias, "Müller-Graaf, Carl-Hermann" in: Neue Deutsche Biographie 18 (1997), S. 497 f. [Online-Version]; URL: https://www.deutsche-biographie.de/pnd106753606.html\#ndbcontent

${ }^{30}$ For the entire text of the Trade Agreement signed in December, see: AJ, 9-114, Dostavljanje teksta o razmeni robe i plaćanjima za 1950. godinu, 16. 1. 1950.

${ }^{31}$ BAK, B 102/6194, Mn,Rat Dr. C.H. Müller an Herrn Oberbergrat a.D. Keyser, 3. 1. 1950; Dr. Ludwig Erhard an den Herrn Bundeskanzler der BRD, 12. 1. 1950.

32 BAK, B 102/6194, Mn,Rat Dr. C.H. Müller an Herrn Oberbergrat a.D. Keyser, 3. 1. 1950; Dr. Ludwig Erhard an den Herrn Bundeskanzler der BRD, 12. 1. 1950; Ellz Störring, Fürsorgerin, an das Bundeswirtschaftsministerium, betr. Das deutsch-jug. Handelsabkommen, 23. 1. 1950.

${ }^{33}$ AJ, 9-114, Dostavljanje teksta o razmeni robe i plaćanjima za 1950. godinu, 16. 1. 1950.

${ }^{34}$ BAK, B 102/6194, Vermerk. Herrn Dr. v. Maltzan über Herrn Dr. Müller vorzulegen, 19. 1. 1950.

${ }^{35}$ BAK, B 102/6194, Deutscher Bundestag - 32. Sitzung. Bonn, Freitag, den 27. Januar 1950, $1012-1013$. 
and an attempt at pressuring the Yugoslav side following the failure of unofficial interventions by diplomatic means. ${ }^{36}$ The issue of the German POWs was officially in the realm of the ministry of justice since early 1950 , but due to its complicated nature, the ministry of economy remained deeply involved. German industrialists were not so fond of this bundling because they saw it as an obstacle to Germany's trade interests. Their concerns were seconded by parts of the ministry of economy as well. ${ }^{37}$ However, following the successful resolution of a similar issue with Yugoslav-Italian trade negotiations, many became convinced that this course of action was justified. ${ }^{38}$

In February of 1950 the Allied High Commission signed off on the agreement, removing the last remaining formal obstacle for its ratification. Discussions arose over whether the previously halted shipments of scrap metal were to be continued. The Hamburg Company Coutinho, Caro \& Co was entrusted with delivering the remaining 25,000 tons of scrap metal to Yugoslavia. In early February, its representative Dr. Vessel requested an export license from the ministry of economy. The ministry of economy and the chancellor's office began debating this issue. The chancellor himself, despite his Bundestag speech, was essentially against making the release of prisoners a condition for exporting scrap metal. ${ }^{39}$ The trade-political committee ${ }^{40}$ supported the ratification of the agreement, while suggesting that the head of the German trade delegation, Otto Stahlmann, should convey to the Yugoslavs that future trade relations would depend on the political atmosphere, which could be improved only by resolving the POW issue. ${ }^{41}$ On the other hand, Herbert Schelpepper ${ }^{42}$ from the economic administration $^{43}$ was convinced that any further shipments of scrap metal were unnecessary in light of the political troubles, since the previously sent 15,000

\footnotetext{
${ }^{36}$ BAK, B 102/6194, Horstmann an Herrn Fr. Jur. c. Springsfeld, 17. 2. 1950.

${ }^{37}$ BAK, B 102/6194, Bericht über eine 14-tägige Reise Schweiz, Italien, Jugoslawien; BAK, B 102/6194, Herrn Hauptabteilungsleiter V vorzulegen, betr. Deutsche Kriegsgefangene in Jugoslawien, 23. 2. 1950; BAK, B 102/6194, "Schwierigkeiten in deutsch-jugosl. Handel", Außenhandels- Auskunfts- und Beratungsbüro, 1. Beiblatt, Nr. 9, 1. 3. 1950.

${ }^{38}$ BAK, B 102/6194, Edmund Jans an das BMW, Referat Jugoslawien, 30. 1. 1950; BAK, B 102/6194, Dr. von Maltzan an den Bürgermeister von Wuppertal, Herrn Dr. Klaus Brauda, 4. 3. 1950 .

${ }^{39}$ BAK, B 102/6194, Betr. Deutsche Kriegsgefangene in Jugoslawien..., 10. 2. 1950.

${ }^{40}$ The Trade-Political Committee (der Handelspolitische Ausschuß) was an interministerial body responsible for coordinating West German foreign trade.

${ }^{41}$ BAK, B 102/6194, Auszug. Niederschrift über die Sitzung des Handelspolitischen Ausschusses am 10. 2. 1950.

42 Between 1941 and 1943 Herbert Schelpepper was advisor to the German Military Administration in Belgrade, in charge of foreign political issues and issues related to customs. After the war, he worked in the West German Ministry of Economy, in departments for East and Southeast Europe. See: Bernhard Löfler, Soziale Marktwirtschaft und administrative Praxis. Das Bundeswirtschaftsministerium unter Ludwig Erhard (Wiesbaden: Franz Steiner Verlag, 2002), 178.

43 The British and American occupation forces in Germany founded economic Administration (Verwaltung für Wirtschaft) on January 1, 1947, when the British and American zones of occupation merged. Although the duties of the Economic Administration were entrusted to the Ministry of Economy in September of 1949, the Economic Administrated existed until April of 1950.
} 
tons had already exceeded the quarterly quotas. ${ }^{44}$ Heinz Trützschler von Falken$\operatorname{stein}^{45}$ from the chancellor's office, as well as C. H. Mueller, the representative of the department for iron and steel, suggested that the initial 10,000 tons be sent only after receiving guarantees of no more executions as well as promises of amnesty, and that the remaining 15,000 tons should be sent only after the Yugoslav side kept its promises. In their opinion, private channels, in this case Coutinho, Caro \& Co, should also be employed in conveying the West German stance to the Yugoslavs. ${ }^{46}$

Dr. Vessel did not agree with such an approach, as he thought that a private company should not be conveying ultimatums and stated that he would not participate in negotiations that could endanger further cooperation. He also emphasized the intolerance toward criticism by the Yugoslav regime and speculated that such an initiative would only worsen the conditions of the German prisoners. ${ }^{47}$ A compromise was soon reached. The channels his firm established in Yugoslavia were used in order to initiate talks with Yugoslav representatives regarding the prisoners. ${ }^{48}$ The company was granted a license to export the initial 10,000 tons of scrap metal, desperately needed by the Yugoslav industry. During the following 20 days, a meeting was to be held in Zurich between Yugoslav and German representatives with the aim of successfully resolving the prisoner issue, after which the remaining 15,000 tons would be shipped. Yugoslav Consul Milanović carried these proposals to Belgrade. ${ }^{49}$

Milanović's trip to Belgrade remained largely unsuccessful, ${ }^{50}$ but he was soon joined by Vladimir Gavrilović, head of the Yugoslav Trade Mission in Frankfurt who, according to West German sources, had traveled to Yugoslavia to help resolve the prisoner issue ${ }^{51}$ Upon his return to Germany on 7 March, Gavrilović requested audience with the ministry of economy, refusing to divulge the details to anyone else. His request was delivered to Erhard, with a note - "EILT VERTRAULICH" (urgent secret). ${ }^{52}$

44 BAK, B 102/6194, An Herrn C.H.Müller, betr. Schrottlieferungen nach Jugoslawien, 11. 2. 1950.

${ }^{45}$ Heinz Trützschler von Falkenstein was a prewar German diplomat, and a member of the NSDAP. In 1949, he was employed in the Chancellor's Office and was in charge for relations with the Allied High Commission. In 1951, he started working in the Ministry of Foreign Affairs, initially in the subdivision responsible for German POWs. The West German Government proposed him for the post of Ambassador in Belgrade, but the Yugoslav side rejected, with an explanation that they could not give agrément to a "Ribentropp's" diplomat. Hans Kroll, Lebenserinnerungen eines Botschafters (Berlin-Darmstadt-Wien: Deutsche Buch-Gemeinschaft, 1968), 281-282.

${ }^{46}$ BAK, B 102/6194, Betr. Deutsche Kriegsgefangene in Jugoslawien..., 10. 2. 1950.

${ }^{47}$ BAK, B 102/6194, Dr. Vessel. Fuer Herrn Ministerialrat dr. C.H. Müller, 11. 2. 1950.

${ }^{48}$ BAK, B 102/6194, Vermerk betr. Schrottlieferungen nach Jugoslawien, 30. 3. 1950.

${ }^{49}$ BAK, B 102/6194, Vermerk betr. Deutsche Kriegsgefangene in Jugoslawien, 14. 2. 1950.

${ }^{50}$ BAK, B 102/6194, Vermerk über Besprechung vom 20. 2. 1950, 21. 2. 1950; Vermerk betr. Schrottlieferungen nach Jugoslawien, 30. 3. 1950.

${ }^{51}$ BAK, B 102/6194, Herrn Hauptabteilungsleiter V vorzulegen, betr. deutsche Kriegsgefangene in Jugoslawien, 23. 2. 1950.

52 BAK, B 102/6194, Herrn Minister vorzulegen, betr. Besuch des Leiters der jugoslawischen Handelsdelegation Dr. Gavrilovic, 7. 3. 1950. 
Two days later, on 9 March 1950, Erhard received Gavrilović, who briefly informed the German minister about the exact number of German prisoners in Yugoslavia. He then asked Erhard why the FRG Government not ratified the agreement after the Allied High Commission had approved it. Ludwig Erhard explained that the Federal government was responsible for the German citizens held in Yugoslavia and for their family members in Germany and that the German people were highly sensitive to the prisoner issue and that the Government therefore had to take into consideration the "psychological weight" of relations with Yugoslavia when deciding about the trade agreement. On the other hand, Gavrilović noted that, by raising the prisoner issue in the Bundestag debate and by binding it with the issue of the trade agreement ratification in the "form of an ultimatum", the federal government contributed to such a negative stance of the West German public toward Yugoslavia. Erhard replied that no one but the chancellor himself was responsible for ratifying the agreement and that he would by all means inform him about the conversation. He further added that the federal government had never delivered "ultimatums" to Yugoslavia, thereby expressing his hope that a favorable political atmosphere for ratifying the agreement would be reached soon. ${ }^{53}$ At the same time, the Yugoslav side used unofficial communication channels in order to gather information about possibilities for removing the current obstacle in mutual relations. ${ }^{54}$

In March and April of 1950, it seemed that the opinion of those in the ministry of economy who favored ratifying the agreement had prevailed. A thorough analysis of Adenauer's Bundestag speech from January led to the conclusion that the chancellor had not made the POW issue a condition for ratifying the agreement. C. H. Mueller further added that, neither during the December negotiations nor during the subsequent talks with the Yugoslav representatives, had the German side tied the two issues directly but rather expressed their conviction that a favorable political climate in bilateral relations could be reached by solving the issue of prisoners. ${ }^{55}$ Furthermore, the West Germans were starting to reconsider their assumption about influencing the Yugoslavs to release the German prisoners by hindering further scrap metal exports. ${ }^{56}$ They felt that the fact the FRG had been delivering scrap metal to Yugoslavia without previously ratifying the agreement had been contrary to West German interests. On the one hand, the aims and the consequences of non-ratification had been compromised, and on the other hand, the Yugoslavs were being given an excuse for their inflexibility. C. H. Mueller thought that by ratifying the agreement the federal government would gain the arguments and the means to exert moral as

${ }^{53}$ BAK, B 102/6194, Aufzeichnung über eine Besprechung zwischen Bundeswirtschaftsminister Prof. Dr. Ludwig Erhard und dem Leiter des jug. Wirtschaftsmision Dr. Gavrilovic, 9. 3. 1950.

${ }^{54}$ BAK, B 102/6194, Aufzeichnung. Herrn Dr. Dittmann mit der Bitte vorgelegt, eine Entscheidung des Herrn Bundesministers herbeizuführen, 24. 3. 1950.

55 BAK, B 102/6194, Dr. C.H.Müller über den Herrn Staatssekretär Herrn Bundesminister für Wirtschaft ergebenst vorgelegt, betr. Jugoslawien, Verknüpfung der Zeichnung des Handelsvertrages mit der Kriegsgefangenenfrage, 14. 3. 1950.

${ }^{56}$ BAK, B 102/6194, Vermerk betr. Schrottlieferungen nach Jugoslawien, 30. 3. 1950. 
well as economic pressure on the Yugoslavs, as they were in dire need of much greater amounts of scrap metal than the December agreement specified. ${ }^{57}$ Furthermore, the ministry of economy concluded that the West German economy in fact suffered by not ratifying the agreement, as selective export licenses and halted exports contributed to Yugoslavia's negative trade balance and threatened those industrial branches that counted on imports from Yugoslavia. ${ }^{58}$ Furthermore, the negative long-term effects of stagnation in trade relations were also outlined. The West Germans feared that their economic position in the Balkans could be jeopardized and replaced on the Yugoslav market by the United States, the United Kingdom, France, Italy, and Sweden. ${ }^{59}$ On top of that, the Allied High Commission was not supportive of the FRG's efforts to solve the POW issue by exerting economic pressure on Yugoslavia. ${ }^{60}$

Having all this in mind, the West Germans tried once again to solve the accumulated troubling issues through diplomacy, away from the public eye. In the meantime, they had learned that the issue of German prisoners had a "psychological" dimension for the Yugoslav side as well. Namely, West German sources stated that Yugoslav leaders and party members witnessed German atrocities during World War II, which posed an obstacle for the authorities in Belgrade in their attempts to explain to the Yugoslav people that trade relations and economic recovery outweighed justice for war crimes. Furthermore, the sources cautioned against pressuring the Yugoslavs, who could, as a result, become even more unyielding. During the unofficial talks, which took place on 18 March 1950, the Yugoslavs presented a draft proposal for resolving the issue of the remaining German prisoners. The proposal suggested releasing the German prisoners that had not been sentenced, reexamining the personal responsibilities of those sentenced to prison, amnesty for those sentenced to death, as well as improving the living conditions for the Germans remaining in Yugoslav prisons. In return, the West German Government would publicly renounce its support for those prisoners whose personal guilt had been proven. Furthermore, they would not champion the change in Yugoslavia's attitude as a major foreign political success, nor celebrate the return of prisoners with bombastic headlines. ${ }^{61}$ The fact is that the Yugoslavs were frustrated by the fact that each and every agreement they made with the West was being used in anti-Yugoslav campaigns in the East.

Ludwig Erhard suggested proposing to the Yugoslav side to make the first step, which would enable the West German Government to publically de-

${ }^{57}$ BAK, B 102/6194, Dr. C. H. Müller über den Herrn Staatssekretär Herrn Bundesminister für Wirtschaft ergebenst vorgelegt, betr. Jugoslawien, Verknüpfung der Zeichnung des Handelsvertrages mit der Kriegsgefangenenfrage, 14. 3. 1950.

${ }^{58}$ BAK, B 102/6194, Herrn Bundesminister für Wirtschaft über Herrn Staatssekretär vorzulegen, betr. Deutsche Kriegsgefangene in Jugoslawien, 3. 4. 1950.

${ }^{59}$ BAK, B 102/6194, Herrn Bundesminister für Wirtschaft über Herrn Staatssekretär vorzulegen, betr. Deutsche Kriegsgefangene in Jugoslawien, 3. 4. 1950.

${ }^{60}$ BAK, B 102/6194, Auszug aus einem Bericht des Herrn Direktor Jäger von Haniel\&Lueg vom 30. 3. 1950.

${ }^{61}$ BAK, B 102/6194, Anlage 2. Kriegsgefangene in Jugoslawien, 20. 3. 1950. 
clare that hopes were running high that the question of the German prisoners would be resolved in the near future. ${ }^{62}$ C. H. Mueller met with Gavrilović on 29 March $1950 .^{63}$ Gavrilović was presented with a list of West Germany's essential conditions, previously agreed with the chancellor. They included the request for the Yugoslav side to present evidence against those sentenced for war crimes, revoke death sentences, release those who were not personally responsible for committing war crimes, improve the living conditions of the prisoners remaining in Yugoslav internment and allow them visits and exchange of letters. The West Germans also requested that further negotiations should not be conducted publicly. If the Yugoslavs accepted Bonn's requests, the federal government would issue a statement informing the German public that conditions for ratifying the trade agreement with Yugoslavia had been met. ${ }^{64}$ Gavrilović set out for Belgrade immediately. ${ }^{65}$

Furthermore, in early April of 1950, the Allies increased their pressure on Bonn to ratify the trade agreement with Yugoslavia. At a meeting between Chancellor Adenauer and the high commissioners on 5 April 1950, US General George Hays ${ }^{66}$ said that the Allied governments were incapable of helping the FRG with the issue of German prisoners in Yugoslavia as long as the trade agreement remained unratified. He therefore asked Konrad Adenauer to reconsider ratifying the agreement. ${ }^{67}$

Eventually, the Yugoslav side responded favorably to the West German requests presented during the talks between V. Gavrilović and C. H. Mueller and as a result Stanislav Kopčok, a representative of the Yugoslav Foreign Trade Ministry, arrived in West Germany. The talks in Bonn on 11 and 12 April 1950 concentrated on two issues - resolving the issue of the remaining German prisoners of war and finding a common ground for long-term economic cooperation. On 11 April, Kopčok informed the West German side that out of the 830 German prisoners still in Yugoslav captivity, 72 had been sentenced to death and subsequently given amnesty, 500 had been sentenced to 15-20 years in prison, 160 to $10-15$ years in prison, 54 to $6-10$ years, 40 to 5 years, and 2 prisoners had been sentenced to life imprisonment. Although insisting that both the Yugoslav laws and the will of the Yugoslav people had to be respected, he underlined the Yugoslav Government's readiness to reduce the sentences and

${ }^{62}$ BAK, B 102/6194, Aufzeichnung. Herrn Dr. Dittmann mit der Bitte vorgelegt, eine Entscheidung des Herrn Bundesministers herbeizuführen, 24. 3. 1950.

${ }^{63}$ BAK, B 102/6194, Entwurf. Ludwig Erhard, an den Kanzler der BRD Herrn Dr. h.c. Konrad Adenauer, betr. Deutsche Kriegsgefangene in Jugoslawien. Zeichnung des deutschjugoslawischen Handelsvertrages, 13. 4. 1950.

${ }^{64}$ BAK, B 102/6194, Herrn Bundesminister für Wirtschaft über Herrn Staatssekretär vorzulegen, betr. Deutsche Kriegsgefangene in Jugoslawien, 1. 4. 1950.

${ }^{65}$ The document states that Gavrilović set out for Yugoslavia on Thursday, which was most probably March 30.

${ }^{66}$ George Price Hays was replacing at the time absent High Commissioner John McCloy.

${ }^{67}$ PA AA, B2/183, Besprechung des Bundeskanzlers Dr. Adenauer mit den Hohen Komissaren auf dem Petersberg, 5. 4. 1950. 
gradually, in the course of 2 or 3 years, release all the German prisoners. ${ }^{68}$ Kopčok claimed he had no instructions to sign any agreements related to prisoners directly and that the negotiations were aimed at achieving mutual understanding. Nevertheless, he stated that the federal republic's readiness to increase economic cooperation with Yugoslavia would greatly speed up the return of the prisoners. In clear terms, the Yugoslav side sought the FRG's readiness to commit to signing a long-term economic agreement and a corresponding credit agreement with Yugoslavia, in order to have their political requests met. ${ }^{69}$

In the view of the Germans, the Yugoslav wishes were concurrent with their own interests, especially in light of the growing competition with the British on the Yugoslav market. Germany was interested in importing grains, lumber, copper, and cattle fodder from Yugoslavia. As a result, Ludwig Erhard asked the chancellor to support Kopčok's initiative, and to expedite the procedure of ratifying the December agreement. ${ }^{70}$ Over the course of these discussions, the issue of prisoners was raised once again on 14 April. C. H. Mueller requested the complete list of the remaining German prisoners in Yugoslavia and supported the opening of a West German trade mission in Belgrade. This mission would enjoy consular rights and be responsible for the care of all German citizens in Yugoslavia. ${ }^{71}$ Having received the chancellor's approval, Ludwig Erhard wrote in a letter to Stanislav Kopčok dated 15 April, saying that West Germany was eager to negotiate an economic agreement with Yugoslavia, which would include an investment for factories valued between 80 and 100 million dollars, as well as additional credits, which would be repaid through Yugoslav exports. ${ }^{72}$

The trade agreement of December 1949 was ultimately ratified on 18 April 1950 and was soon followed by a communiqué in which the federal government stated that it would not support those German citizens personally responsible for war crimes in Yugoslavia. Consequently, transports carrying German prisoners sentenced to prison for war crimes began arriving from $\mathrm{Yu}-$ goslavia. By October of 1950, 344 prisoners sentenced to short-term incarceration had returned..$^{73}$ During the same time, preparations were being made for establishing trade missions in Bonn and Belgrade. The Yugoslav economic delegation was accredited with the Allied High Commission in late 1950 and essentially became Yugoslavia's most important diplomatic mission in West

${ }^{68}$ BAK, B 102/6194, C.H. Müller, Aufzeichnung, 12. 4. 1950.

${ }^{69}$ BAK, B 102/6194, Entwurf. Ludwig Erhard an den Kanzler der BRD, betr. Deutsche Kriegsgefangene in Jugoslawien, Zeichnung des deutsch-jugoslawischen Handelsvertrages, 13. 4. 1950.

${ }^{70}$ BAK, B 102/6194, Entwurf. Ludwig Erhard an den Kanzler der BRD, betr. Deutsche Kriegsgefangene in Jugoslawien, Zeichnung des deutsch-jugoslawischen Handelsvertrages, 13. 4. 1950.

${ }^{71}$ BAK, B 102/6194, C.H. Müller an das Bundeskanzleramt, z.Hd. von Herrn Dr. von Trütschler, 14. 4. 1950; Diplomatski arhiv Ministarstva spoljnih poslova Republike Srbije (DA MSP), Politička arhiva (PA), Nemačka, 1950, f. 74, dos. 1, dok. 410574, Beleška o razgovoru održanom u Ministarstvu privrede dana 14. o.m.

${ }^{72}$ BAK, B 102/6194, Ludwig Erhard an Stanislav Kopčok, 15. 4. 1950.

${ }^{73}$ Kurt W. Böhme, Die deutschen Kriegsgefangenen in Jugoslawien 1949-1953, Band I/2, (Bielefeld: Verlag Ernst und Werner Gieseking, 1976), 336. 
Germany. It enjoyed all diplomatic rights, including coded messaging, radio communication, diplomatic license plates, and diplomatic immunity. The same provisions would apply to the West German mission in Belgrade. ${ }^{74}$ The first head of the Yugoslav economic delegation, Stane Pavlič, arrived in Bonn in November of 1950. During his very first meetings with the West German leaders, mutual commitment to improving cooperation was noted and the issue of German prisoners was once again raised. The head of the political department in the chancellor's office praised Yugoslavia's "forthcomingness" in such an important issue and the chancellor himself expressed hope that all German prisoners would be granted amnesty soon. Adenauer stressed the "psychological importance" of this act for improving bilateral relations. ${ }^{75}$

When Pavlič's counterpart Robert Ulrich ${ }^{76}$ was received by Josip Broz Tito for the first time, he said that "truly amicable" relations between the two countries could be achieved only after the remaining prisoners had been released. ${ }^{77}$ Ulrich's pleas were not left unanswered. Over the course of 1951, Yugoslavia released 530 German prisoners. The following year, an additional 118 were sent home, and the final 11 prisoners were freed on 25 March 1953. Only prisoners extradited to Yugoslavia by third countries remained in custody, as did around 150 Volksdeutsche. ${ }^{78}$

The issue of prisoners of war was never on the fringes of YugoslavWest German relations during the early '50s. It carried considerable psychological weight for both countries. The plight of the remaining POWs in Yugoslavia resonated with the German population in light of their own living conditions under occupation. On the other hand, the Yugoslavs had an understandable desire to punish those responsible for war-time atrocities and destruction.

This issue also had a political dimension. For the West German Government, its successful resolution could greatly increase their support amongst the voters. The West German electorate consisted not only of families and

${ }^{74}$ DA MSP, PA, Nemačka, 1950, f. 74, dos. 12, dok. 421586, Zabeleška o razgovoru ministra Pavliča sa zamenikom šefa protokola savezničke Visoke komisije za Zapadnu Nemačku, 14. 11. 1950; DA MSP, PA, Nemačka, 1950, f. 74, dos. 12, dok. 422359, Zabeleška o razgovoru savetnika Perišića sa zamenikom šefa protokola i v.dužnosti šefa Daunonom u Protokolu V.S. Komisije u Petersbergu, 28. 11. 1950.

${ }^{75}$ DA MSP, PA, Nemačka, 1950, f. 74, dos. 12, dok. 421586, Zabeleška o razgovoru ministra Pavliča sa zamenikom šefa protokola savezničke Visoke komisije za Zapadnu Nemačku, 14. 11. 1950; „Dok. Nr. 163: Aufzeichnung des Vortragenden Legationsrats Dittmann, 12. Dezember 1950“, in: Akten zur Auswärtigen Politik der Bundesrepublik Deutschland 1949/1950, 163-164.

${ }^{76}$ Robert Ulrich was a prewar German diplomat, who was discharged in 1935 due to his Jewish origins. Upon returning from British emigration, he started working at the West German Ministry of Foreign Affairs. In 1951, he became the first political representative of the FRG in Yugoslavia, and the first West German diplomatic representative in Belgrade between December 1951 and his death in January 1952. https://www.bundesarchiv.de/aktenreichskanzlei/19191933/0000/adr/adrsz/kap1_3/para2_7.html (pristupljeno 4. 5. 2020).

77 „Dok. Nr. 142: Generalkonsul I. Klasse Ulrich, z.Z. Bled, an das Auswärtige Amt, betr. Erstes Gespräch mit Tito, 22. August 1951“, in: Hrsg. Hans-Peter Schwarz, Akten zur Auswärtigen Politik der Bundesrepublik Deutschland 1951 (München: R. Oldenbourg Verlag, 1999), 459-462.

${ }^{78}$ K. W. Böhme, Die deutschen Kriegsgefangenen in Jugoslawien 1949-1953, I/2, 336. 
friends of those detained in Yugoslav prisons, but also of former prisoners of war, friends and families of those imprisoned in other countries, war veterans, and refugees. All of them were very sympathetic toward the plight of the remaining prisoners of war in Yugoslavia. According to Hans Kroll, the future West German Ambassador in Belgrade, the release of prisoners from Yugoslavia meant "several hundred thousand votes" for Chancellor Adenauer at the forthcoming elections in September of $1953 .{ }^{79}$

On the other hand, the Yugoslavs had to at least appear reluctant to release their German prisoners, as they were facing serious charges from the East. Their swift untimely release would add fuel to the charges of "revisionism" and "fascism" that were abundant in the Eastern Bloc's anti-Yugoslav propaganda campaign. However, although undoubtedly damaging, these accusations also served as justification for Yugoslavia's unyielding stance. For example, when Radio Prague broadcast that "fascist Yugoslavia had freed 120 German war criminals" and that "over 30,000 former German soldiers were now serving in the Yugoslav Army", the Yugoslav diplomats in Germany were quick to remind their German colleagues of the damning nature of such charges. While denouncing the lies from the East, they underlined Yugoslavia's readiness to cooperate in releasing the remaining German prisoners of war. ${ }^{80}$

Lacking foreign political strength, the federal government in Bonn resorted to economic pressure. The tactic of bundling together economic and political questions would be employed often during the following years within Yugoslav-German relations. On this occasion, such bundling was mutually beneficial. The German side had to resort to economic pressure as the only available option, whereas Yugoslavia could trade the remaining prisoners for economic benefits. Yugoslavia could count on the support of the Western Allies, who had pressured the West German Government to be forthcoming toward Yugoslavia's demands in light of the Yugoslav-Soviet split. Despite the fact that both German envoys to Yugoslavia during the early '50s, Robert Ulrich and Hans Kroll, could count on the chancellor's support for the tying together trade and political negotiations, some important figures in the West German establishment were against such a tactic. German industrialists in particular were unsympathetic toward any obstacles to the rising German economic presence in Yugoslavia, whereas the Bank of German States had warned against Germany's overly ambitious financial commitments.

The years 1950 and 1951 proved crucial for the development of Yugoslav-West German relations. For the first time, there was a political will to overcome the negative legacy of the past. Although the long shadow of the recent war could not be dispersed overnight, the first Yugoslav ambassador in Bonn could proclaim jubilantly in January of 1953 that no open questions re-

\footnotetext{
${ }^{79}$ H. Kroll, op. cit., 239.

80 DA MSP, PA, Nemačka, 1951, f. 60, dos. 16, dok. 45266, Zabeleška o razgovoru savetnika Perišića sa zamjenikom državnog sekretara za vanjske poslove Dr Dittmannom, održanom 13. aprila 1951. u Bonnu.
} 
mained in Yugoslav-West German relations, at the same time stressing the productive trade cooperation and generous German investments and loans. ${ }^{81}$ That same year, his German counterpart, Hans Kroll, boasted to Chancellor Adenauer that he had successfully carried out the first task he had been given upon arriving in Belgrade, namely, alleviating the psychological and practical consequences of the war, especially the issue of the German prisoners. ${ }^{82}$

81 Darko Bekić, Jugoslavija u Hladnom ratu. Odnosi s velikim silama 1949-1955 (Zagreb: Globus, 1988), 494.

${ }^{82}$ H. Kroll, op. cit., 249. 


\section{REFERENCES}

- Axel, Schildt (ur.). Deutsche Geschichte im 20. Jahrhundert. Ein Lexikon. München, Verlag C. H. Beck, 2005.

- Bekić, Darko. Jugoslavija u Hladnom ratu. Odnosi s velikim silama 19491955. Zagreb: Globus, 1988.

- Böhme, Kurt W. Die deutschen Kriegsgefangenen in Jugoslawien 1941-1949. Band I/1. Bielefeld: Verlag Ernst und Werner Giesking, 1976.

- Böhme, Kurt W. Die deutschen Kriegsgefangenen in Jugoslawien 1949-1953, Band I/2. Bielefeld: Verlag Ernst und Werner Gieseking, 1976.

- Diehl, James. The Thanks of the Fatherland: German Veterans after the Second World War. Chapel Hill-London: The University of North Carolina Press, 1993. (e-book)

- Dimić, Natalija. „Na obnovi Jugoslavije radimo za Nemačku: nemački zarobljenici, antifašisti, propagandisti““. Tokovi istorije, br. 2, (2020), 75-105. https://doi.org/10.31212/tokovi.2020.2.dim.75-105

- Dokumenti o spoljnoj politici Socijalističke Federativne Republike Jugoslavije 1949. Beograd: Jugoslovenski pregled, 1991.

- Geppert, Dominik. Die Ära Adenauer. Darmstadt: WBG, 2007.

- Hadži-Jovančić, Perica. The Third Reich and Yugoslavia: An Economy of Fear, 1933-1941. Bloomsbury, 2020. https://doi.org/10.5040/9781350138087

- Hnilicka, Karl. Das Ende auf dem Balkan 1944-1945. Die Militärische Räumung Jugoslawiens durch die deutsche Wehrmacht. Zürich-Frankfurt: Musterschmidt, 1970.

- Ilić, Saša S. „Stranci gastarbajteri“: Strana stručna radna snaga u privredi Jugoslavije 1945-1950. Beograd: Arhiv Jugoslavije, 2020.

- Ilić, Saša. „Vrednovanje rada i životni uslovi nemačkih ratnih zarobljenika zaposlenih u privredi Jugoslavije 1945-1949“. Istorija 20. veka, br. 2, (2019), 157-176. https://doi.org/10.29362/ist20veka.2019.2.ili.157-176

- Judt, Tony. Postwar. A History of Europe since 1945. New York: The Penguin Press, 2005.

- Kleßmann, Christoph. Die doppelte Staatsgründung. Deutsche Geschichte 1945-1955. Bonn: BpB, 1991.

- Kocić, Milena S. „Ekonomski odnosi Kraljevine Jugoslavije i Nemačke od 1929. do 1941. godine“. Doktorska disertacija, Univerzitet u Nišu, Filozofski fakultet, Departman za istoriju, 2019.

- Kroll, Hans. Lebenserinnerungen eines Botschafters. Berlin-Darmstadt-Wien: Deutsche Buch-Gemeinschaft, 1968.

- Löfler, Bernhard. Soziale Marktwirtschaft und administrative Praxis. Das Bundeswirtschaftsministerium unter Ludwig Erhard. Wiesbaden: Franz Steiner Verlag, 2002.

- Lukač, Dušan. „Privredna ekspanzija Nemačke prema Jugoistoku Evrope 1933-1937“. Balcanica, br. 11, (1980), 163-177. 
- Lukač, Dušan. Treći Rajh i zemlje Jugoistočne Evrope, knj. 3. Beograd: Vojnoizdavački novinski centar/Balkanološki institut SANU, 1987.

- Mitrović, Andrej. "Ergänzungswirtschaft: the Theory of an Integrated Economic Area of the Third Reich and Southeast Europe 1933-1941". In: The Third Reich and Yugoslavia 1933-1945, 7-45. Beograd: Institut za savremenu istoriju/Narodna knjiga, 1977.

- Mitrović, Andrej. "Deutschland und Jugoslawien 1919-1933", Zbornik Filozofskog fakulteta, knj. XII, br. 1, (1974), 567-575.

- Pape, Matthias. "Müller-Graaf, Carl-Hermann". In: Neue Deutsche Biographie, 18, (1997), S. 497 f. [Online-Version]; URL: https://www.deutschebiographie.de/pnd106753606.html\#ndbcontent

- Schmidt-Richberg, Erich. Der Endkampf auf dem Balkan. Die Operationen der Heeresgruppe E von Griechenland bis zu den Alpen. Heidelberg: Scharnhorst Buchkammeradschaft, 1955.

- Schumann, Wolfgang. „Aspekte und Hintergründe der Handels- und Wirtschaftspolitik Hitler-Deutschlands gegenüber Jugoslawien“. In: The Third Reich and Yugoslavia 1933-1945, 221-239. Beograd: Institut za savremenu istoriju/Narodna knjiga, 1977.

- Schwarz, Hans-Peter (ur.). Akten zur Auswärtigen Politik der Bundesrepublik Deutschland 1949/1950. München: R. Oldenbourg Verlag, 1997. https://doi.org/10.1524/9783486718225

- Schwarz, Hans-Peter (ur.). Akten zur Auswärtigen Politik der Bundesrepublik Deutschland 1951. München: R. Oldenbourg Verlag, 1999. https://doi.org/10.1524/9783486718188

- Smith, Jr., Arthur L. „Die deutschen Kriegsgefangenen und Frankreich 19451949“. Vierteljahrshefte für Zeitgeschichte, 32, no. 1, (1984), 103-121.

- Terzić, Milan. „Josip Broz Tito i Nemci - ratni zarobljenici“. Vojnoistorijski glasnik, br. 2, (2015), 164-175.

- Vinaver, Vuk. Svetska ekonomska kriza u Podunavlju i nemački prodor 1929 1935. Beograd: Institut za savremenu istoriju, 1987.

- Weber, Jürgen. Kleine Geschichte Deutschlands seit 1945. München: Deutscher Taschenbuch Verlag, 2002.

- Završne operacije za oslobođenje Jugoslavije. Beograd: Vojnoistorijski institut, 1957. 
MA, NATALIJA DIMIĆ, Research Assistant

Institute for Recent History of Serbia

Belgrade, Republic of Serbia

natalijadimic@gmail.com

CONNECTING TRADE AND POLITICS: NEGOTIATIONS ON THE RELEASE

OF THE GERMAN PRISONERS OF WAR IN YUGOSLAVIA AND THE FIRST WEST GERMAN-YUGOSLAV TRADE AGREEMENT OF 1949/1950

\section{Summary}

After repatriations were officially over in January of 1949, around 1,400 German prisoners remained in Yugoslavia on charges of war crimes. Yugoslavia's foreign political shift westward following the Cominform Resolution of 1948, paved the way for establishing productive economic, as well as political and cultural cooperation with West Germany. The first trade agreement between the two states was signed in December of 1949. In the next four months, the West German Government attempted to pressure the Yugoslav side to release the remaining German prisoners by not ratifying the agreement. Eventually, in April of 1950, the two sides reached an unofficial agreement, according to which the Yugoslav side would release its prisoners gradually and improve their living conditions, while the West Germans would ratify the trade agreement and agree to negotiate long-term economic cooperation. The last transport of German prisoners arrived from Yugoslavia in March of 1953.

KEYWORDS: German Prisoners of War, Federal Republic of Germany, Yugoslavia, German-Yugoslav relations, Trade Agreement, Repatriation, War Crimes 